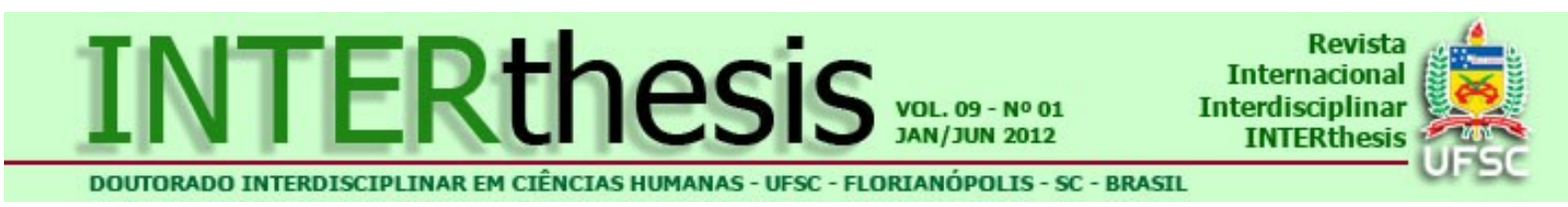

\title{
A ECOLOGIA POLÍTICA NA AMÉRICA LATINA: REAPROPRIAÇÃO SOCIAL DA NATUREZA E REINVENÇÃO DOS TERRITÓRIOS
}

\section{POLITICAL ECOLOGY IN LATIN AMERICA: NATURE'S SOCIAL REAPROPRIATION AND THE REINVENTION OF TERRITORIES}

\section{LA ECOLOGÍA POLÍTICA EN AMÉRICA LATINA: REAPROPIACIÓN SOCIAL DE LA NATURALEZA Y REINVENCIÓN DE LOS TERRITORIOS}

\section{Carlos Walter Porto-Gonçalves ${ }^{1}$}

\section{RESUMO:}

O pensamento/ação ambiental latino-americano vem se desenvolvendo com/contra os fundamentos da matriz de racionalidade eurocêntrica. Essa tradição tem na geopolítica atual o desenvolvimento sustentável como nova forma de colonização/exploração. Com/contra ela, criativamente, corresponde uma série de respostas críticas com o novo protagonismo, a partir das lutas locais/regionais de camponeses, de povos indígenas e de afroamericanos que, no novo contexto geopolítico que se abre pós anos 1960, passam a ter condições de se expressar à escala internacional, inclusive se apropriando dos vetores ecológico e tecnológico. Nos domínios naturais clímato-botânicos que se formaram desde o fim da última glaciação, evoluindo para as geografias atuais, as populações originárias desenvolveram um rico acervo de conhecimentos construídos numa relação com e não contra a natureza que, tal como a mega-diversidade biológica, é um patrimônio de nossa região e da humanidade e que deve ser considerado nas políticas públicas. Surge um novo léxico teórico-político em que se fala de descolonização, de interculturalidade, de transmodernidade; de pluralismo jurídico, que respeite os direitos das gentes, consuetudinários, não mais somente o direito fundado nos princípios liberais do indivíduo e da propriedade privada. Ao lado dos conflitos envolvendo água, mineração e grandes projetos de desenvolvimento, vê-se a emergência de uma série de experiências ricas e originais de sustentabilidade: as Reservas Extrativistas, o Parque Nacional de Yasuny; os Direitos da Natureza constitucionalizados na Bolívia e no Equador; o Estado Plurinacional; o Buen Vivir, o Suma Qamaña e o Suma Kausay: ideias para uma nova agenda política, um rico patrimônio cultural e natural que nos servem de baliza para reinventar a nossa existência. Nesse contexto, os conceitos de território, de territorialidades e territorialização possibilitam compreender as relações da sociedade com a natureza,

\footnotetext{
${ }^{1}$ Doutor em Ciências pela Universidade Federal do Rio de Janeiro (UFRJ). Professor adjunto da Universidade Federal Fluminense (UFF), pesquisador do CNPq e do Conselho Latinoamericano de Ciências Sociais - CLACSO. E-mail: cwpg@uol.com.br
}

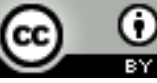


cerne da problemática ambiental, explicitando que o que está em jogo é a luta pela reapropriação social da natureza (Enrique Leff).

Palavras-chave: Ecologia política. América Latina. Descolonização. Território. Buen Vivir.

\section{ABSTRACT:}

The Latin American environmental thinking/action has been growing with/against the fundamentals from the Eurocentric rationality matrix. This tradition has in the present geopolitics the sustainable development as its new colonization/exploration form. With/against it, a creative and critical series of answers corresponds to this matrix, with the protagonism of peasants, indigenous peoples and African Americans, based in their local/regional struggles. In the post 1960 geopolitical context, these peoples obtain conditions to express themselves in an international scale, including the ecological and technological vectors. In the climate-botanical natural domains that, formed since the end of the last glaciation, evolved to our present geographies, the original populations developed a rich estate of knowledge, built in one with and not against the nature relationship that, like the biological megadiversity, is a patrimony of Latin America and mankind that must be taken into account in the public policies. In their new political/theoretical lexicon they speak about decolonization, interculturality, transmodernity; a juristic pluralism that respects the rights of the peoples, consuetudinary, not more only the law based on individual liberal principles and the private property. Besides the struggles involving water, mining and big development projects, a series of rich and original sustainability experiences emerge: Extractive Reservations, the Yasuny National Park; the constitutional Rights of Nature in Bolivia and Ecuador; the Plurinational State; the Buen Vivir, Suma Qamaña and Suma Kausay: ideas for a new political agenda, a rich natural and cultural estate that serve to us as landmarks for the reinvention of our existence. Accordingly, the Territory, Territorialities and Territorialization concepts allow to understand the relationships between nature and society, the kernel of the environmental problematic, revealing that it is the Nature's social reapropriation that is at stake (Enrique Leff).

Keywords: Political ecology. Latin America. Decolonization. Territory. Buen Vivir.

\section{RESUMEN:}

El pensamiento/acción ambiental latinoamericano viene desarrollándose con/contra los fundamentos de la matriz de racionalidad eurocéntrica. Esa tradición tiene, en la geopolítica actual, al desarrollo sustentable como nueva forma de colonización/explotación. Con/contra ella, creativamente, corresponde una serie de respuestas críticas con el nuevo protagonismo, a partir de las luchas locales/regionales de campesinos, de pueblos indígenas y de afroamericanos que, en el nuevo contexto geopolítico que se abre pos años 1960, pasan a tener condiciones de expresarse a escala internacional, inclusive apropiándose de los vectores ecológico y tecnológico. En los dominios naturales climático-botánicos que se formaron desde el fin de la última glaciación, evolucionando para las geografías actuales, las poblaciones originarias desarrollaron un rico acervo de conocimientos construidos en una relación con y no contra la naturaleza que, tal como la megadiversidad biológica, es un patrimonio de nuestra región y de la humanidad y que debe ser considerado en las políticas públicas. Surge un nuevo léxico teóricopolítico en que se habla de descolonización, de interculturalidad, de transmodernidad; de pluralismo jurídico, que respete los derechos de las gentes, 
consuetudinarios, no más solamente el derecho fundado en los principios liberales del individuo y de la propiedad privada. Al lado de los conflictos envolviendo agua, minería y grandes proyectos de desarrollo, se ve el surgimiento de una serie de experiencias ricas y originales de sustentabilidad: las Reservas Extractivas, el Parque Nacional de Yasuny; los Derechos de la Naturaleza constitucionalizados en Bolivia y en Ecuador; el Estado Plurinacional; el Buen Vivir, el Suma Qamaña y el Suma Kausay: ideas para una nueva agenda política, un rico patrimonio cultural y natural que nos sirven de baliza para reinventar nuestra existencia. En este contexto, los conceptos de territorio, de territorialidades y territorialización posibilitan comprender las relaciones de la sociedad con la naturaleza, cierne de la problemática ambiental, explicitando que lo que está en juego es la lucha por la reapropiación social de la naturaleza (Enrique Leff).

Palabras clave: Ecología Política. América Latina. Descolonización. Territorio. Buen Vivir.

"Não há defesa da floresta sem os povos da floresta"

(Chico Mendes)

Os anos 1960 constituem um verdadeiro divortium aquarium político-cultural. Novas questões foram trazidas ao debate público e novos grupos sociais se constituíram com elas. À época a questão de gênero começa a ganhar destaque com o movimento das mulheres; a questão étnico-racial passa a afirmar-se, seja em função da descolonização dos povos asiáticos e africanos, seja através do movimento negro estadunidense; o movimento ecológico começa a por em debate a questão ambiental, seja através da crítica à corrida armamentista, seja através da crítica à "sociedade do desperdício" (PACKARD, 1965). Também do ponto de vista do conhecimento os anos 1960 abriram novos horizontes epistêmicos, em grande parte relacionados a esse intenso debate político-cultural.

Desde então a idéia de que há limites para a intervenção humana na natureza ganha força. A ciência, sobretudo depois da invenção pelos físicos da bomba atômica e de seu uso em Hiroshima e Nagasaki, perdia definitivamente sua inocência e mostrava que não necessariamente está a serviço da vida ou da emancipação humana, conforme a promessa iluminista. Em 1951, na baía de Minamata, no Japão, toda uma comunidade de pescadores se viu contaminada por mercúrio lançado na água ${ }^{2}$. O homem não escapava das cadeias tróficas, das

\footnotetext{
${ }^{2} \mathrm{O}$ envenenamento estava relacionado à fábrica de acetaldeído e PVC de propriedade da Chisso, indústria de fertilizantes químicos. À época era difícil falar publicamente contra a companhia, pois ela era um empregador importante na cidade. Pesquisas médicas concluíram que várias mortes foram causadas por envenenamento com mercúrio em função do consumo de peixe contaminado. $O$
} 
cadeias alimentares, como acreditara o antropocentrismo. A crise da ciência não só ética, mas de seus próprios fundamentos, pelo menos na sua vertente hegemônica positivista e estrutural-funcionalista, abria espaço para outras matrizes de racionalidade até então desqualificadas pelo eurocentrismo e sua colonialidade que desprezava outras experiências humanas e seus conhecimentos próprios.

Desde a Primavera Silenciosa (1962), de Rachel Carson, Population Bomb (1968), de Paul Erlich, da Estratégia do Desperdício de Vance Packard (1965), do The Economic Process and the Entropy Law de Nicholas Georgescu Roegen (1971), do The Limits to Growth de Meadows e Meadows (1972), do Para una crítica de la ecologia política, de Hans Magnus Enzensberg (1973), até O Mito do Desenvolvimento de Celso Furtado (1974), que o debate sobre a natureza ganha dimensões políticas explícitas. Nesse contexto é que a ONU convocou a primeira Conferência mundial para debater meio ambiente, em Estocolmo, em 1972. Definitivamente a problemática ambiental entrava na agenda geopolítica internacional.

A questão ambiental coloca em xeque o desdobramento produtivista (tanto na sua vertente liberal como socialista) de um projeto civilizatório de origem européia que tem na idéia antropocêntrica de dominação da natureza um dos seus pilares. Com a questão ambiental a dimensão epistêmica, técnica e política se imbricam, sobretudo pela centralidade que a economia passa a ter na vida social (LEFF, 2006). A separação entre as ciências humanas e as ciências naturais, além das especializações no interior de cada um desses campos, corresponde à separação (expulsão) dos camponeses e dos povos originários da natureza, além da destruição das suas comunidades, dos seus territórios e suas territorialidades tornando-os indivíduos que, tal como se dirá na filosofia de Spinoza, tornam-se mônadas. A busca da unidade indivisível será objeto de uma verdadeira obsessão epistêmica na biologia, com a célula ou a molécula; na física com o átomo e nas ciências sociais com o indivíduo que o liberalismo, sobretudo no período neoliberal, levará ao paroxismo com o individualismo. A naturalidade com que se crê, no mundo científico, que os mistérios da natureza se revelam em linguagem matemática encontra seu correspondente no mundo mundano onde cada vez mais a vida de cada um está mediada pela quantificação mercantil. A quantificação da vida

mercúrio, usado no complexo Chisso como catalisador, é também utilizado em lâmpadas fluorescentes e fosforescentes e traz sérios riscos à saúde e ao meio ambiente. 
cotidiana pela mercantilização generalizada da vida torna-a banal e, assim, a quantificação parece natural. Afinal, os paradigmas não caem dos céus, ao contrário, são instituídos no mundo mundano de nossas vidas.

São profundas as implicações do debate contemporâneo sobre a natureza, o que nos insta a por em questão a própria tradição de pensamento que forjamos e que nos forjou. Trata-se de um debate epistêmico e político a uma só vez. A idéia de dominação da natureza subjaz ao desenvolvimento científico e tecnológico contemporâneo, sobretudo depois que, tal como Prometeu, dominamos o fogo - ou melhor, os combustíveis fósseis, carvão e petróleo - que produziria o calor que moveria as máquinas. Com isso deixamos escapar um princípio que os fisiocratas haviam percebido quando diziam que só a natureza criava riqueza líquida - "uma semente pode produzir mil sementes" - e que eles mesmos não foram capazes de projetar para fora do mundo da agricultura. Afinal, a descoberta do carvão como fonte de energia no mundo da indústria ratifica o princípio fisiocrático de que a natureza participa do processo de criação da riqueza. A energia contida numa molécula de carbono, embora descoberta pelo homem, não foi e não é produzida por ele. Nenhum país, nenhuma sociedade produz ferro, petróleo ou água. Ao contrário do que crê o antropocentrismo e um de seus desdobramentos, a ideologia produtivista que grassa entre liberais e certas correntes marxistas, somos extratores porque não os produzimos ${ }^{3}$. Essa é uma das principais razões de tanto conflito territorial onde, por exemplo, os Estados Unidos, com todo o seu desenvolvimento científico e tecnológico, necessariamente precisa manter milhares de bases militares em todo o mundo para obter os minerais que nenhuma ciência/técnica produz. Ao

\footnotetext{
${ }^{3}$ Essa distinção entre extrator e produtor é essencial. Afinal, considerarmo-nos como produtores implica acreditar que podemos produzir (fazer) tudo o que usamos: é o antropocentrismo. Considerarmo-nos extratores implica considerar que extraímos algo que não fazemos e, assim, que devemos estabelecer limites à nossa relação com tudo que não fazemos. Afinal, como na melhor tradição racionalista, devemos nos relacionar com as coisas de acordo com a sua natureza. Assim, estamos mais para Spinoza (1632-1677) do que para Descartes (1596-1650). E antes que algum tecnocrata queira dizer quais são os limites para a relação com a natureza, esclareçamos que limite tem em sua origem relação direta com a palavra polis, significando o limite que separava a cidade do campo. Limite é o cerne da política e só tem sentido na pluralidade dos homens/mulheres com a prerrogativa de iniciarem a ação política, como nos ensina Hannah Arendt. Enfim, a política só tem sentido na democracia não cabendo mais somente ao Príncipe a prerrogativa de principiar a ação. $O$ Príncipe, já nos ensinou Gramsci, não está mais nos palácios e sim no mundo mundano, onde se devem instituir as hegemonias. O limite da relação da sociedade com a natureza, portanto, não é técnico, mas sim político, ainda que qualquer que seja a solução política haverá que se fazer operacional enquanto técnica. Há, todavia, uma perspectiva teórico-política que se quer não-política e, por isso, se vê como meramente técnica. Talvez tenhamos que recuperar Maquiavel (1469-1527) que, melhor que qualquer outro pensador, explicitou essas técnicas próprias da política.
} 
contrário do pensamento evolucionista, as sociedades desenvolvidas com base nessa crença dependem da natureza assim como qualquer outra sociedade.

Enfim, a matriz de racionalidade hegemônica no mundo ocidental, sobretudo a partir do iluminismo e da revolução (nas-relações-sociais-e-de-poder) industrial, foi desenvolvida para dominar a natureza, fundamento de seu "magma de significações imaginário" (CASTORIADIS, 1982). E, como é da natureza das relações de dominação, todo ser que é dominado não é respeitado em seu próprio ser, nas suas virtualidades e potencialidades, porquanto é considerado somente nas suas qualidades que podem servir ao dominador. Dominação é, sempre, em algum grau, a negação do outro, o que é válido tanto para povos, para etnias, para grupos e/ou classes sociais como para a natureza. O aquecimento global pode ser visto como parte dessa relação de sujeição, de dominação, enfim do efeito sobre o planeta dos rejeitos acumulados na atmosfera (efeito estufa). O mesmo pode ser dito da desagregação da matéria e do lixo (poluição da terra, das águas, do ar) até aqui tratados como externalidades, conceito que só tem sentido a partir de uma episteme que considera o homem - res cogitans - fora da natureza - res extensa. Portanto, o debate em torno da sustentabilidade é um debate epistêmico e político (Luis Macas).

Deste modo uma abordagem da ecologia política desde a perspectiva latinoamericana exige repensar os fundamentos da matriz de racionalidade eurocêntrica. Mesmo quando a economia tenta se mostrar ecológica, o tem feito nos marcos de um logocentrismo que atribui valores monetários à natureza e, assim, acaba por confundir as coisas da lógica com a lógica das coisas (POLANYI, 1980; LEFF, 2006; BARTRA, 2008). Enfim, confunde a medida do calor, a temperatura, com o calor em sua materialidade. E, não estamos diante de questões filosóficas, como pudemos ver no debate que se deu com a crise de 2008 quando se manejaram conceitos como os de "economia financeira e/ou fictícia" e de uma "economia real", onde se opôs o "capital especulativo" ao "capital produtivo", olvidando aquilo que o economista catalão Joan Martinez Alier chamou de "economia real-real" (MARTíNEZ ALIER, 2009): aquela que vê a inserção dos processos produtivos na natureza, enfim, na sua inscrição territorial, haja vista que a "retomada do crescimento" desejada pelos ideólogos do mainstream e até por muitos dos seus críticos, ignora essa inscrição. Como assinalou Max-Neef "a economia é um subsistema de um sistema maior que é finito, a biosfera, portanto, o crescimento permanente é 
impossível". "As diferenças de emissões (de gases de efeito estufa) entre indivíduos, em função de seu grau de riqueza e de seus padrões de consumo (...) mostra que os 500 milhões de pessoas mais ricas do mundo ( $7 \%$ da população) emitem metade dos gases de efeito estufa lançados na atmosfera" (ABRAMOVAY, 2010).

\section{A FALÁCIA DA DESMATERIZALIZAÇÃO DA PRODUÇÃO}

Há uma crença acrítica no poder da tecnociência, quase uma religião, que chega até mesmo a falar, sem muita cerimônia, em milagres da tecnologia. Embora se registre que, hoje (2012), cada unidade de dólar ou euro é produzida com 30\% menos de materiais que há 30 anos, houve, nesse mesmo período, um aumento de $50 \%$ na demanda desses materiais. "Ora, uma vez que o consumo de recursos dos norte-americanos é, em média, de 88 quilos diários por habitante e o dos africanos ao Sul do Sahara de apenas dez quilos diários (FRIENDS OF EARTH et al, 2009), a generalização dos padrões de consumo que marcam os modos de vida dos mais ricos conduziria certamente a um grau de pressão sobre os ecossistemas incompatível com a manutenção dos serviços básicos que eles prestam à espécie humana. Claro que o progresso técnico e o avanço no sentido de produzir com cada vez menos materiais e energia são decisivos. Mas é perigosamente ilusório imaginar que a redução da desigualdade pode ser compatível com a generalização dos padrões de consumo que hoje marca a vida destes $7 \%$ da população mundial responsáveis por metade das emissões de gases de efeito estufa" (ABRAMOVAY, 2010).

Estocolmo 1972 significa um marco no processo de institucionalização da problemática ambiental, mas não olvidemos o papel instituinte dos movimentos sociais dos anos 1960 ao pautarem o debate acerca dos limites da intervenção humana na natureza. As transformações que o mundo experimentará a partir dos anos 1970, que alguns chamarão de período neoliberal e outros simplesmente de globalização, nos anos 1980 tem a questão ambiental como uma das questões mais debatidas. A natureza passa a ser resignificada diante de transformações de fundo nas relações-sociais-e-de-poder por meio da tecnologia que conformam um novo ciclo longo de acumulação e crescimento econômico com a biotecnologia, a química fina, a micro-eletrônica, a informática, a engenharia genética, a nanotecnologia, a robótica (PORTO-GONÇALVES, 2006). O germoplasma, por exemplo, passa a ser 
uma fonte de acumulação de capital, ensejando que grandes corporações transnacionais comecem a disputar o sentido a ser dado à natureza. A etnobiopirataria $^{4}$ se aprofunda ao mesmo tempo em que o capital procura legitimá-la através de novas leis de patentes estendendo o princípio da propriedade privada não só às plantas e aos animais, mas também ao mundo nanoscópico do gene ${ }^{5}$. A nanotecnologia aprofunda a fronteira da expansão do capital para o interior da matéria, inclusive da matéria viva ${ }^{6}$. Até mesmo o clima é financeirizado (CORNETTA, 2011) com a recente conversão do capital à causa do aquecimento global, o que vem contribuindo para promover um perigoso consenso em torno do aquecimento global ${ }^{7}$.

A captura da ciência pela lógica financeira tem sido importante não só na conformação da opinião pública - até recentemente o aquecimento global era

\begin{abstract}
${ }^{4}$ A etno-biopirataria é um conceito que procura assinalar que não são as plantas e animais que são contrabandeados das regiões habitadas por camponeses e povos indígenas, via de regra áreas ricas em biodiversidade e água. O que é contrabandeado e levado para os países onde estão os grandes laboratórios químico-farmacêuticos é o conhecimento que esses camponeses e esses povos indígenas têm de plantas e animais, seja como remédio, seja como alimento, seja como ornamento. Enfim, o que é pirateado é o conhecimento sobre plantas e animais e não somente as plantas e os animais.

${ }^{5}$ Não são pequenas as implicações políticas desse fato. Afinal, até aqui todos os povos inventaram sua relação com a natureza a partir dos organismos e não com o gene. O gene só é observável através de instrumentos laboratoriais e não a olho nu, como até aqui estávamos acostumados todos. Não é qualquer um que vê o gene ou tem condições materiais para vê-lo. Assim, há um deslocamento do locus de produção do conhecimento do "espaço banal" da vida onde todos podem ver para os laboratórios, novos centros industriais capturados pelo capital, suas novas fábricas.
\end{abstract}

${ }^{6}$ Nano é uma unidade de medida equivalente ao diâmetro de um fio de cabelo dividido 60 mil vezes. Observemos, mais uma vez, que com o "fio de cabelo" estamos procurando traduzir para o campo da vida mundana, onde até muito recentemente todos participávamos da invenção e construção de sentidos, o significado de "nano", uma unidade de medida comum nos laboratórios técnico-científicos do capital industrial. A ciência, a técnica e a cultura estão, definitivamente, politizadas.

${ }^{7}$ Há controvérsias no campo científico quanto às mudanças climáticas, embora pouco a pouco se forme um consenso quanto à contribuição da ação humana para isso. Para nós, essa ação humana deve ser sempre vista como conformada por determinadas relações sociais e de poder (PortoGonçalves, 2006; Bartra, 2008). Por exemplo, as atuais relações sociais e de poder que conformam o sistema mundo moderno-colonial estão subordinadas a uma lógica quantitativa que se acredita sem limites, como a racionalidade imanente ao capital. No debate acerca das mudanças climáticas, a expressão aquecimento global vem ganhando destaque. Desde o campo da geografia, há uma crítica à ênfase dada à escala global, com o que se deixa de lado outras escalas onde as mudanças climáticas têm agentes e processos mais claramente identificáveis. Não se pode responsabilizar o aquecimento global pela mudança climática regional do sudeste do Pará, onde é grande o desmatamento e opera o complexo de violência e devastação que une a exploração madeireira à fabricação de ferro gusa para exportar minério de ferro puro para o primeiro mundo e, fechando o ciclo do complexo, a criação de gado. Não se pode responsabilizar o aquecimento global pela destruição de povoados pela erosão de praias e dunas ao longo da costa norte do Espírito Santo (Barra do Riacho), onde é grande o desequilíbrio hídrico gerado pela agricultura capitalista em latifúndios monocultores de árvores para produção de celulose para exportação. Não se pode responsabilizar o aquecimento global pelos deslizamentos de encostas e alagações como as provocadas pelo furacão Katrina no sul dos EEUU, em 2005; em Cuzco, no Peru, em Angra dos Reis, na Colômbia e na Venezuela, em 2010; na região serrana do Rio de Janeiro ou na Austrália, em 2011. 
negado pelos grandes meios de comunicação e pelos ideólogos do mainstream como também na definição de parâmetros que permitam ao mercado financeiro desenvolver oportunidades de negócios como os MDL - Mecanismos de Desenvolvimento Limpo - e pelo programa REDD+ - Redução de Emissões pelo Desmatamento e pela Degradação das Florestas. Enfim, a fundamentação científica tem sido necessária para a definição dos parâmetros técnicos para afirmar os interesses das grandes corporações em criar um "mercado de carbono". Desde a Conferência das Partes realizada em Copenhague, em 2009, e em Cancun, em 2010, que o setor financeiro vem ampliando sua ação e fazendo com que o Protocolo de Quioto pouco a pouco vá perdendo importância, como também o princípio das "responsabilidades comuns, mas diferenciadas" que, de certa forma abrigando a luta dos povos colonizados, reconhecia que a atmosfera, enquanto espaço comum da humanidade, havia sido apropriada de modo desigual pelos países colonizadores que se beneficiaram lançando gases de efeito estufa desde a revolução nas-relações-sociais-e-de-poder industrial no século XVIII, gases esses que permanecem na atmosfera por um período calculado entre 80 e 100 anos após a emissão. Com os MDL, as grandes corporações podem comprar o direito de poluir através de $\operatorname{cotas}^{8}$ a que teriam direito os países que não tiveram condições de se industrializarem e, nessa mesma matriz epistêmica que comanda a industrialização, sequer de poluírem. E, ainda, com o REDD mercantilizam as florestas delegando ao mercado a responsabilidade de não desmatá-las. Um dos setores que mais se beneficiam dessas tratativas é o das ONGs, com enormes implicações para os movimentos sociais na medida em que seus espaços de ação passam cada vez mais a ser intermediados por essas organizações "neo-governamentais"9 que

${ }^{8}$ Daí a importância da ciência definir os parâmetros, enfim, dar as referências para que se estabeleçam as cotas. Sem essas normas o mercado não funciona. É preciso ver até que ponto o consenso em torno do aquecimento global não está sendo produzido por técnicos interessados em gerar parâmetros para viabilizar a economia mercantil-capitalista verde.

"Nota conceitual: a expressão "neo-governamental" me parece cientificamente mais adequada que "não-governamental" haja vista que no novo regime de regulação que vivemos, que o léxico político (neo)liberal chama governança, cada vez mais as organizações multilaterais, como o Banco Mundial, por exemplo, lançam mão dessas organizações cuja definição pela negativa de governos dá conta de suas implicações com esse ideário. O mundo das ONGs ao profissionalizar a ação social desloca seu eixo de ação despolitizando-o, papel historicamente exercido pelos movimentos sociais e partidos políticos. O mundo das ONGs não funciona sem financiamento dos Estados, através dos governos (o que por si só desqualifica a expressão não-governamental), das grandes corporações transnacionais através das suas fundações e, já vimos, das organizações multilaterais que são formalmente interestatais embora fortemente influenciadas pelos gestores financeiros e corporativos em geral (PEREIRA, 2009). Matéria publicada no jornal O Globo de domingo dia 12/01/2011 falava que anualmente 600 bilhões de dólares circulam no mundo da filantropia empresarial através de ONGs, o 
operam muita mais na lógica da cooperação e do consenso e negam o contraditório e o dissenso. (É sabido que um verdadeiro consenso só pode ser conseguido a partir do dissenso, como se pode depreender de pensadores tão díspares como Hannah Arendt e Jacques Rancière).

Já não há mais consenso do destino a ser dado à Amazônia, por exemplo: até os anos 1970, o desenvolvimento na região era sinônimo de derrubar a floresta e, agora, a própria floresta com sua riqueza de biodiversidade é objeto de interesses de setores do capital. Tratando-se de uma região cuja ocupação se deu e se dá com formas de apropriação outras que não o direito formal que, diga-se de passagem, não reconhece as formas de apropriação comunitárias tradicionais, quase sempre consuetudinárias, e sendo terras ocupadas por populações originárias há milhares de anos, ou por populações que ali viram oportunidade de se tornarem livres como os ciemarrones/quilombolas, enfim, sendo essas terras com regulação jurídica formalmente precária, tornam-se suscetíveis às pressões para incorporá-las ao mercado, haja vista a grande pressão gerada pela demanda internacional de commodities, agora, ampliada com a financeirização das florestas (MDL e REDD+), ou pela demanda de commodities vinda do oriente (China). Até mesmo um novo tipo de latifúndio vem se constituindo, o latifúndio genético, com a proposta de criar unidades de conservação ambiental que impedem populações de ocupar áreas consideradas de interesse ecológico, muitas das quais habitadas há milhares de anos. A ironia da história, e aqui mais ainda da geografia, é que as regiões que são visadas para serem demarcadas como unidades de conservação de uso restrito, definidas quase sempre pela ciência convencional, são exatamente aquelas que, por terem ficado à margem do mercado e ocupadas por populações tradicionais com outras matrizes de conhecimento, são as regiões que abrigam a maior riqueza em água e em biodiversidade do planeta. Não sem razão, o camponês-seringueiro Chico Mendes (1944-1988) se batendo contra a mentalidade hegemônica e as práticas a ela associadas, propôs as reservas extrativistas afirmando ser esta a forma da "reforma agrária" tal como vista pelos seringueiros e, assim, se antecipando, contrariamente, a esses latifúndios genéticos (PORTO-GONÇALVES,

que dá conta dos enormes desafios que se colocam para os movimentos sociais, sobretudo os antisistêmicos que, como se sabe, sempre cumpriram um papel importante nas conquistas sociais mesmo no interior do sistema, conforme a lúcida observação de Eric Hobsbawn quando afirmou que "nós, socialistas, somos responsáveis por algo que não queríamos: civilizamos o capitalismo, quando queríamos transformá-lo". 
2002 e 2004). Temos assim uma nova geopolítica com a globalização e o desenvolvimento sustentável como nova forma de colonização/exploração, a que criativamente corresponde uma série de respostas críticas dos povos da América Latina.

Desta forma, são enormes as implicações políticas para uma região, como a América Latina, que conta com a maior reserva genética do mundo, como as matas tropicais e equatoriais (Mata Atlântica do Brasil, Amazônia, Florestas tropicais do Pacífico colombiano, do Petein, na Guatemala, da Selva Lacandona de Chiapas, México), as savanas (cerrados e llanos), assim como as duas maiores áreas continentais alagadas do planeta (o Pantanal/Chaco, e a planície do rio Araguaia/ilha do Bananal), as estepes (Patagônia), a puna andina e ainda os mangues/humedales (do Caribe ao Maranhão) e os páramos que ocupam amplas áreas de nosso continente. Algumas dessas regiões são particularmente ricas, megabiodiversas, como os contrafortes andino-amazônicos, as serras do istmo centroamericano e a zona de tensão ecológica (ecótonos) que circunscreve os cerrados (savanas) brasileiros. (figura 1).

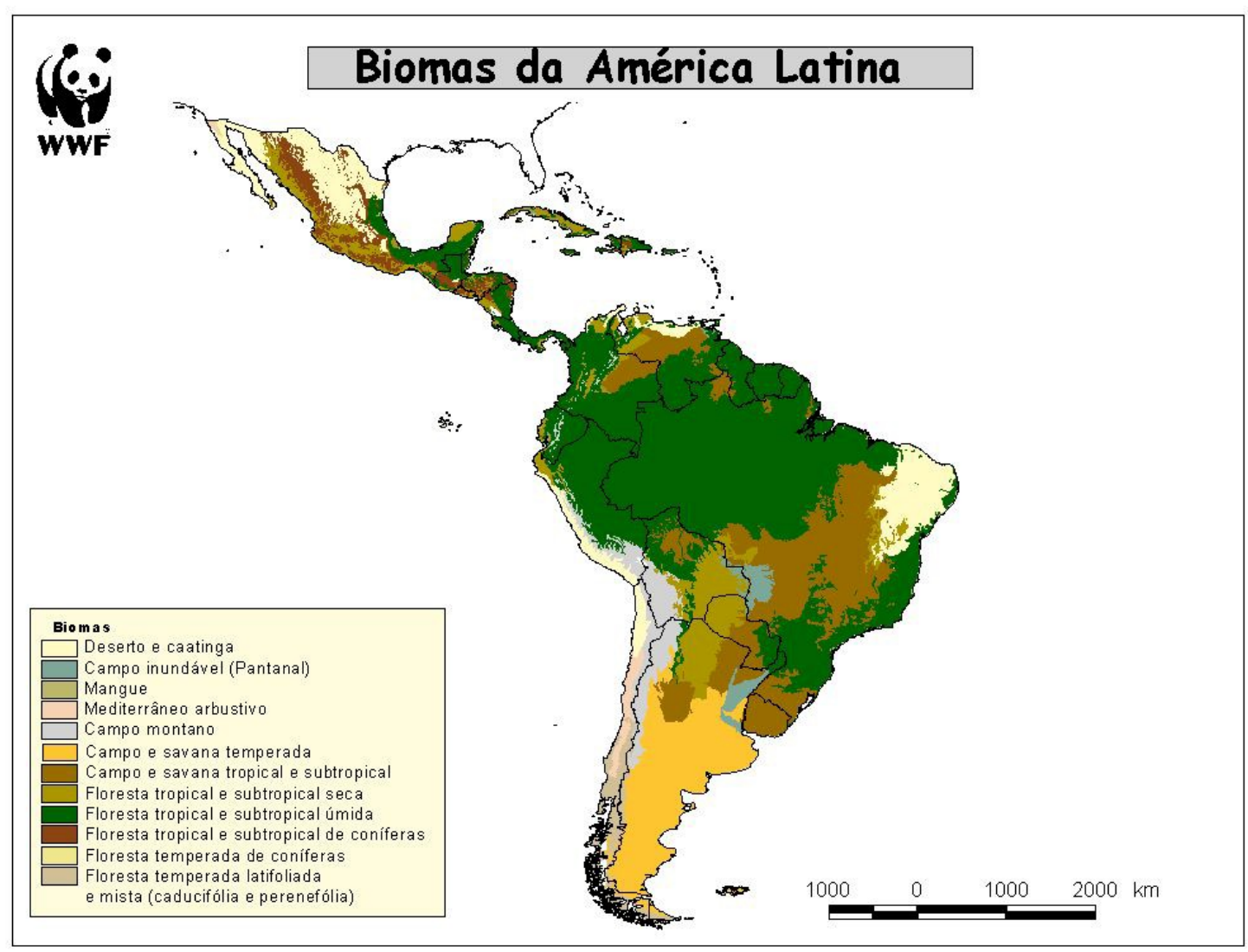

Figura 1 - Biomas da América latina.

Fonte: WWF (2005)

R. Inter. Interdisc. INTERthesis, Florianópolis, v.9, n.1, p.16-50, Jan./Jul. 2012 
Entre a conferência de Estocolmo, de 1972, e a do Rio de Janeiro, em 1992, um novo protagonista ganhou a arena política mundial a partir das lutas locais/regionais: os camponeses e os povos indígenas. O esvaziamento da escala nacional pela hegemonia do capital financeiro e o uso das novas tecnologias de comunicação que permitem o funcionamento 24 horas do dia do mercado financeiro global, também proporcionou que grupos sociais subalternizados, sobretudo os povos indígenas, os camponeses e os afroamericanos (quilombolas, cimarrones, marroons) marginalizados no interior das fronteiras nacionais passassem a ter condições de se expressar à escala internacional, inclusive se apropriando do vetor ecológico que, como assinalamos, passara a fazer parte da agenda geopolítica global, particularmente desde 1972.

Uma abordagem da ecologia política vista desde a América Latina não pode ignorar esse contexto em que se dá a institucionalização dessa problemática no novo período do sistema mundo moderno-colonial que se abre desde os anos 1970. Há uma contribuição específica da nossa região a esse debate teórico-político. Não se pode negar que desde o primeiro momento em que o debate ambiental começa a ganhar as ruas, a polis, ainda em finais dos anos sessenta, a clivagem Norte-Sul que atravessa o sistema mundo moderno-colonial esteve presente. A crítica à sociedade do desperdício (consumismo/produtivismo), por exemplo, foi acompanhada pelo respeito aos povos, países e regiões cujas populações viviam em condições subumanas e não consumiam o mínimo necessário à sua existência. O debate acerca da natureza do desenvolvimento foi acionado e nele Celso Furtado teve um papel pioneiro ao problematizar essa idéia, ele que, até então, fora um dos seus principais defensores. Josué de Castro, desde a primeira hora, esteve atento a essa problemática e nos ofereceu um artigo seminal sob 0 título Subdesenvolvimento: causa primeira da poluição, escrito em 1972, às vésperas da Conferência de Estocolmo (CASTRO, 2003).

Muito embora correntes hegemônicas da esquerda marxista tivessem, de início, criticado o ecologismo, o fato é que diferentes movimentos sociais, sobretudo na América Latina, começaram a assimilar a questão ambiental à sua agenda política. Junto com esses movimentos se desenvolveram importantes correntes teórico-políticas no campo ambiental: a "ecologia popular", o "ecologismo dos pobres" e o eco-socialismo - onde se destacaram intelectuais como o líder 
seringueiro Chico Mendes, assim como o epistemólogo mexicano Enrique Leff, o economista catalão Joan Martinez Alier que tem fortes ligações com movimentos sociais latino-americanos, o antropólogo colombiano Arturo Escobar, o biólogo e antropólogo mexicano Victor Toledo, o sociólogo marxista brasileiro Michel Löwy, entre tantos. Essa contribuição teórica-política é tão importante para compreender os complexos processos sócio-históricos que estão curso como são, ainda hoje, as teses de José Carlos Mariátegui elaboradas nos anos vinte do século passado, a Teoria da Dependência, sobretudo em sua vertente marxista (Rui Mauro Marini e Theotonio dos Santos), a Pedagogia do Oprimido (Paulo Freire), a Teologia da Libertação (Frei Beto, Leonardo Boff, Enrique Dussel), assim como o Pensamento Descolonial (desde Franz Fanon e Aimé Cesaire, ambos caribenhos, até o mexicano Pablo González Casanova, a aymara-boliviana Silvia Rivera Cusicanqui e o peruano Aníbal Quijano). A essas contribuições devemos acrescentar a dos negros estadunidenses que denunciaram o racismo ambiental e, depois, estenderam seus fundamentos ao mundo inaugurando o movimento pela justiça ambiental. $\mathrm{O}$ racismo ambiental se desenvolveu a partir da constatação que o lixo radioativo, nos Estados Unidos, estava destinado às áreas habitadas por populações negras pobres. $O$ desdobramento para o movimento pela justiça ambiental se deu quando a tentativa de retirar o lixo daquelas áreas habitadas por negros pobres nos EEUU se fazia buscando transferi-lo para os países africanos e latino-americanos. O caso mais dramático é o da costa da Somália, onde empresas européias e estadunidenses vêm lançando tonéis com lixo radioativo, que vieram à tona com o tsunami de 2004, aproveitando-se do desmonte do estado somali e de sua fragilidade para garantir suas águas territoriais, conforme documentos da ONU divulgados no vídeodocumentário !Piratas! de Juan Falque ${ }^{10}$. Enfim, a colonialidade que conforma o sistema mundo desde 1492 volta a manifestar o racismo que lhe é constitutivo e se estende da América Latina aos guetos negros estadunidenses e à África, como se vê.

Nossa opção teórica de considerar o espaço como "acumulação desigual de tempos"11 (Santos, 1996) abandonando a perspectiva linear tão característica do

\footnotetext{
${ }_{11}^{10}$ Consultar http://dotsub.com/view/8446e7d0-e5b4-496a-a6d2-38767e3b520a .

${ }_{11}$ Milton Santos sustentava que o espaço geográfico é onde coabitam diferentes temporalidades. Uma das maiores dificuldades que nos são impostas pela colonialidade do saber é a sobrevalorização do tempo em detrimento do espaço. O evolucionismo deitou fortes raízes na tradição eurocêntrica que se impôs ao mundo como se fora a única universalidade possível. Com isso
} 
eurocentrismo, nos obriga a incorporar à análise um tempo de larguíssima duração, para além até mesmo da longa duração de Fernand Braudel, e que habita a geografia latino-americana conforme sugere também Boaventura de Sousa Santos (SANTOS, 2010).

Cerca de 12000 anos atrás o desenho dos domínios clímato-botânicos de nosso continente ainda apresentava uma Amazônia em grande parte coberta por savanas (Figura 2), onde as florestas estavam reduzidas a algumas ilhas, como nos mostra Aziz Ab'Saber em sua "teoria dos refúgios". E, mais, a essa época já havia presença humana junto a essas ilhas de floresta e em meio às savanas ${ }^{12}$

impôs seu provincianismo em nome da universalidade. É isso que possibilita chamar alguns povos de atrasados, como se cada povo e/ou região do mundo fosse um estágio do desenvolvimento europeu. Assim, o espaço e os povos e suas culturas são invisibilizados, não falam, ou melhor, não são ouvidos e não sendo ouvidos são inviabilizados politicamente A simultaneidade é desconsiderada pela eleição de uma temporalidade a partir da qual os outros são ordenados. Há, sempre, diferentes temporalidades convivendo no espaço geográfico As dificuldades de pensar espaço e tempo não se restringem à física quântica e relativística.

${ }^{12}$ Ainda mais, o fóssil humano mais antigo do Brasil, batizado como Luzia, habitava as savanas de Minas Gerais já há 11.500 anos!

R. Inter. Interdisc. INTERthesis, Florianópolis, v.9, n.1, p.16-50, Jan./Jul. 2012 


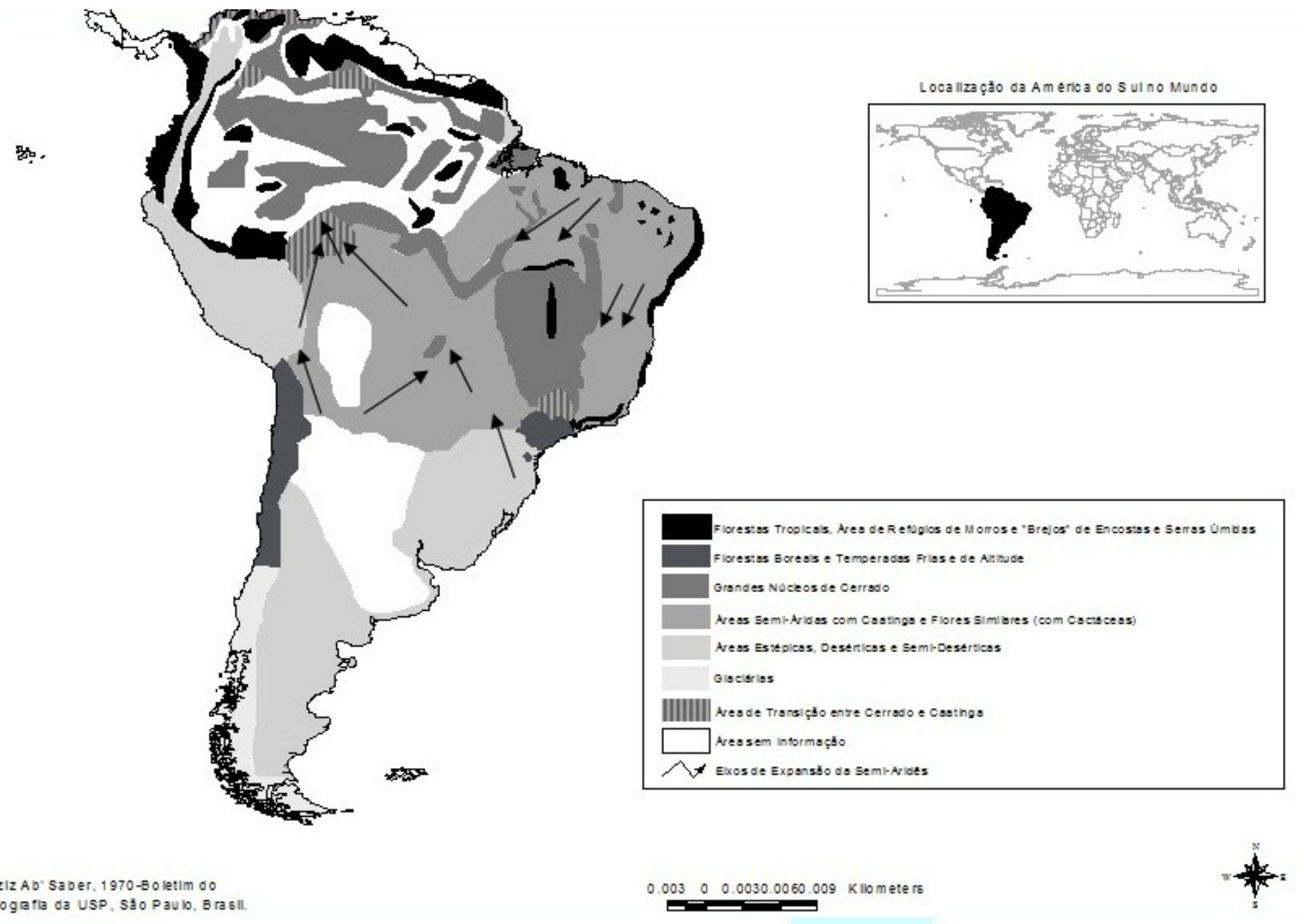

Figura 2 - Dominios Botânicos da América do Sul. Entre 12.000 e 18.000 anos a.p. Fonte: Azis Ab'Saber (1970) 
John Murra (MURRA, 1975) nos legou uma riquíssima análise da organização do espaço geográfico dos povos originários do Tawantinsuyu (quéchuas e aimaras, entre outros) onde os pisos ecológicos andinos eram articulados desde o litoral do Pacífico a oeste, até a região do Chaco-Pantanal e, alguns autores dizem também, interligados ao Planalto Central Brasileiro a leste, onde os princípios de complementaridade e de reciprocidade (ESTERMAN, 2006) comandavam a organização do espaço geográfico ${ }^{13}$.

Há implicações políticas que derivam dessa constatação científica, pois ao mesmo tempo em que os domínios clímato-botânicos foram naturalmente se desenhando e nos oferecendo as geografias que hoje conhecemos (Ver figura 1), várias populações foram desenvolvendo um rico acervo de conhecimentos que, tal como a mega-diversidade biológica, é também um patrimônio que nossa região abriga e que deve ser considerado nas políticas públicas (de regionalização, ambiental, científica e tecnológica). E trata-se de um patrimônio de conhecimentos construídos em grande parte numa relação com e não contra a natureza, o que abre perspectivas de diálogo, sobretudo num momento onde o acervo de conhecimento científico e tecnológico produzido sob o primado da dominação da natureza está sendo colocado em questão, como no caso das mudanças climáticas, da perda de solos, da erosão genética. Esse rico e diversificado patrimônio de conhecimentos dos povos originários, dos camponeses e dos cimarrones/quilombolas nos convida a um diálogo com o conhecimento científico convencional. Aqui, mais uma vez, é preciso superar a colonialidade do saber e do poder que ao ver o outro, o diferente, como inferior, deixou como uma das suas piores heranças o "desperdício de experiência humana" (SANTOS, 2005).

\footnotetext{
${ }^{13}$ Não se trata de divisão territorial do trabalho no mesmo sentido que temos no mundo capitalista onde a divisão do espaço está a serviço de uma classe e tem um sentido quase sempre unidirecional. O politólogo boliviano Luis Tapia retomou esse tema no debate do país acerca da sua nova constituição. Temos aqui um bom exemplo das novas questões teórico-políticas que esses movimentos sociais vêm proporcionando, sobretudo o movimento dos povos originários (TAPIA, 2009).
} 


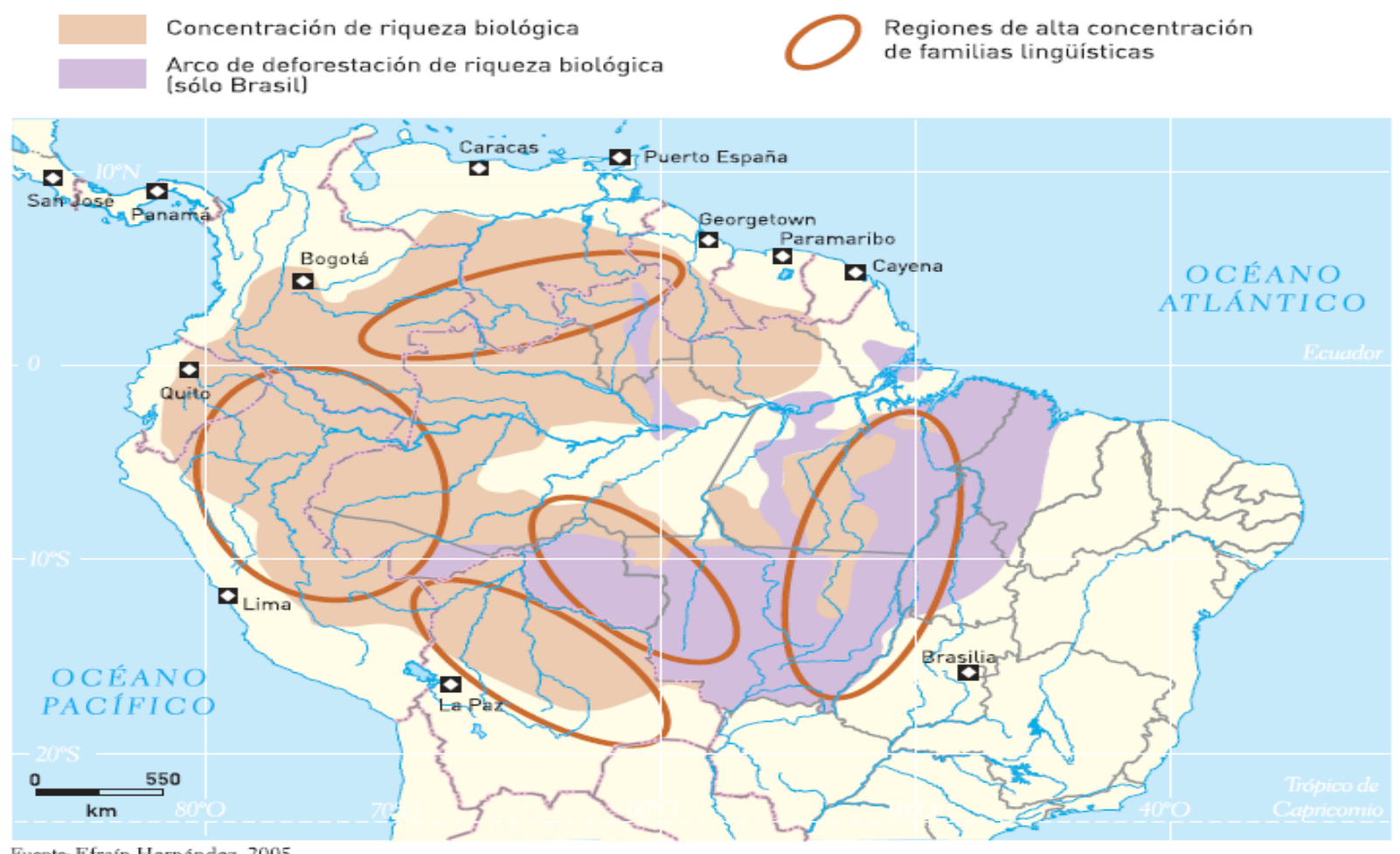

Figura 3 - Diversidade Biológica e Cultural da Amazônia.

Fonte: Efraín Hernández (2005).

\section{DE TERRITÓRIOS, DE TERRITORIALIDADES E DE TERRITORIALIZAÇÃO}

O contexto histórico específico da América Latina e Caribe nesse período de globalização sob hegemonia neoliberal ensejou um debate teórico-político próprio no campo ambiental em que o conceito de território e de seus correlatos territorialidades e territorialização ganham destaque (PORTO-GONÇALVES, 2001; HAESBAERT, 2011). Desde a Declaração de Barbados (1971) até a Convenção 169 da OIT $^{14}$ (1989) e a Declaração dos Direitos dos Povos Indígenas da ONU (2007), que um longo caminho foi percorrido reconhecendo os direitos ao território das populações originárias, dos camponeses e dos afro-americanos que conformaram outras formas de apropriação do espaço. As lutas históricas desses grupos, povos e etnias acabaram ensejando um conjunto de questões teórico-políticas. A nova configuração geopolítica que se desenha com as políticas neoliberais pós-anos 1970 ensejou reformas políticas em vários países, sobretudo no campo ambiental com o reconhecimento dos direitos dos povos originários e de populações

\footnotetext{
${ }^{14}$ De que o Brasil e todos os países sul-americanos são signatários.
}

R. Inter. Interdisc. INTERthesis, Florianópolis, v.9, n.1, p.16-50, Jan./Jul. 2012 
quilombolas/cimarrones que geraram efeitos contraditórios. Essas reformas políticas acabaram por sofrer os efeitos do seu próprio conhecimento, melhor seria dizer desconhecimento, acerca desses povos e grupos sociais, sobretudo das relações de poder que conformam as relações entre grupos sociais e etnias. Na verdade, esse conhecimento/desconhecimento levou a que subestimassem a importância dessas populações camponesas, indígenas e de quilombolas/cimarrones na formação dos estados territoriais de nossa região. Observe o leitor que falamos de estado territorial e não de estado-nação (voltaremos a essa importante questão mais adiante). Talvez a ênfase dada ao direito à diferença com as políticas de identidade nessas reformas, sua ideologia pós-moderna e seu afã de derrotar as grandes narrativas e as teorias que enfatizavam as classes sociais e as lutas de classes, acabaram por não considerar devidamente as imbricações classe/etnia, tão bem assinalada já nos anos 1920 por José Carlos Mariátegui, e raça/classe, conforme a rica contribuição atual de Aníbal Quijano (QUIJANO, 2000). Todavia, é preciso ver que o debate teórico que acompanha essas reformas que, em grande parte silenciava o lado crítico, dava forma jurídico-política a um processo expropriatório de populações camponesas, de povos originários e de cimarrones/quilombolas jamais visto em toda a história da humanidade ${ }^{15}$.

O debate em torno do território se dá, portanto, imerso num tenso e intenso processo expropriatório ${ }^{16}$, desterritorializador, num contexto onde a questão

15 Para que se tenha idéia da magnitude desse processo, segundo o PNUMA (http://www.pnuma.org/geodatos/) entre 1970 e 2010, a população urbana mundial aumentou em 2.177.000.000 de habitantes, ou seja, a cada ano, nos últimos 40 anos, uma cidade de 54 milhões de habitantes acrescentada ao mundo! A população urbana do mundo, em 1990, era maior que a população total do planeta 30 anos antes, em 1960! Na América Latina/Abya Yala, a população urbana, em 2010, era maior que a população total da região 20 anos antes: 475 milhões de habitantes nas cidades em 2010 contra 441 milhões de população total em 1990! Em outros termos, entre 1970 e 2010 tivemos na América Latina/Abya Yala uma nova cidade de oito milhões de habitantes a cada ano! O fenômeno urbano deixa, assim, de ser um fenômeno dos países ditos desenvolvidos e, hoje, $70 \%$ da população urbana mundial está na Ásia, na África e na América Latina. A urbanização realmente existente não corresponde à superioridade atribuída à vida urbana e, não raro, as populações sub-urbanizadas das periferias estão mais suscetíveis às intempéries do que quando estavam no campo, para não falarmos da violência a que estão submetidas e da busca por um "consolo ideal para um mundo que concretamente não tem consolo" (Marx) com o uso das drogas, o verdadeiro "ópio do povo", que cresce juntamente com a presença de igrejas de que, se acreditava, suas religiões seriam um fenômeno da tradição e do mundo rural.

${ }^{16}$ Duas grandes ondas expropriatórias anteriores ocorreram no mundo como parte da constituição do sistema mundo moderno-colonial: 1- a conquista/invasão colonial de Abya Yala/América, desde o início um processo de tensão territorial, que foi acompanhada pela desterritorialização dos povos africanos através do tráfico de escravos; 2- a que se deu nos séculos XVII e XVIII na Europa contra os seus camponeses com a desterritorialização promovida através dos enclousures, ou seja, com o cercamento das suas áreas comuns para instaurar o primado da propriedade privada de cunho capitalista. Esclareça-se que a propriedade camponesa, também na Europa, comportava essa 
ambiental abria um questionamento acerca da relação sociedade-natureza que, embora pautado inicialmente a partir dos países urbano-industrializados e sua matriz epistêmica eurocêntrica, ganha outros contornos com outros protagonistas na América Latina. Aqui, a natureza e a cultura são politizadas com o deslocamento da luta pela terra para a luta pelo território, onde esse conceito adquire outras significações ao apontar que dentro de um mesmo estado-territorial habitam múltiplas territorialidades. O conceito de estado-nação abriga em seu seio um "colonialismo interno" (GONZÁLEZ CASANOVA, 2005) ignorando as múltiplas territorialidades que o território do estado abarca.

Assim, o conceito de território deixa de ser pensado como a base física de exercício da soberania do estado, tal como consagrado no direito internacional e sua ciência jurídica e política, e passa a ser visto como o processo de apropriação e controle do espaço geográfico com seus recursos e suas gentes, revelando as tensas relações de poder que lhes são constitutivas. E como não há apropriação material que não seja acompanhada por um determinado sentido dado por uma cultura, em outras palavras, como não há apropriação material que não seja ao mesmo tempo simbólica, o processo de apropriação da natureza é acompanhado, ao mesmo tempo, por uma tensa e intensa luta pelos sentidos a ela atribuídos. Nesse sentido, a natureza e a cultura são politizadas. Enfim, território é igual à natureza mais cultura através das relações de poder, e essa é uma das principais contribuições da América Latina para a ecologia política. A partir dessa perspectiva, o debate ambiental requer a explicitação das relações sociais e de poder que thes são constitutivas. Enfim, trata-se de um debate teórico-político como bem destacara o agrônomo quéchua-equatoriano Luis Macas, ex-presidente da Coordenadora das Nacionalidades Indígenas do Equador - CONAIE -, quando afirmara que "nuestra lucha es epistémica y política".

Enfim, não há território que não comporte um sentido de controle do espaço seus recursos e suas gentes que, sempre, é conformado por uma territorialidade e que é objeto de um processo histórico-político de apropriação protagonizado por

combinação de propriedade individual (familiar) e uso comum de terras de campos, bosques, águas. Essa combinação de propriedade familiar individual e comunitária é muito mais comum em várias regiões do mundo do que temos admitido (ver nossas terras "gerais"; os ayllus quéchua/aymara; o mir russo (Zasulich/Marx); a territorialidade seringueira (PORTO-GONÇALVES, 2004), dos retireiros do Araguaia e seus "varjões" comuns; os faxinais do sul do Brasil, os fundos de pasto do nordeste brasileiro (CAMPOS, 2000).

R. Inter. Interdisc. INTERthesis, Florianópolis, v.9, n.1, p.16-50, Jan./Jul. 2012 
grupos e/ou classes sociais, povos e etnias. O território se mostra, assim, um conceito que possibilita compreender as relações da sociedade com a natureza, cerne da problemática ambiental, explicitando as relações de poder que a atravessam. Assim, ultimamente o conceito de território vem sendo desnaturalizado (PORTO-GONÇALVES, 2004; RAFFESTIN, 1985, HAESBAERT, 2011, SACK, 1985, HARVEY, 2005) - para isso, muito vem contribuindo a luta dos camponeses, dos povos originários, dos quilombolas/cimarrones - e, cada vez mais, é visto a partir dessa tríade constitutiva território-territorialidade-territorialização.

O conceito de território e tudo que nele está implicado nos ajudam a compreender o que está em jogo com a questão ambiental, ou seja, a luta pela reapropriação social da natureza, conforme a feliz expressão de Enrique Leff (LEFF, 2006). Afinal, a condição da reprodução das relações de produção capitalistas é a permanente separação dos povos e etnias das condições materiais de existência natureza incluída, além do caráter comunitário do modo de vida e de produção - e, com homens e mulheres individualizados, de um lado, e com a natureza sem gente de outro, uns e outros podem se tornar mercadorias. Em suma, a questão ambiental, quase sempre reduzida a uma genérica relação sociedade-natureza, se mostra, no fundo, enquanto questão que implica a reapropriação social da natureza. Com isso, a tríade território-territorialidade-territorialização se torna uma questão teóricopolítica de primeira ordem.

Desde finais dos anos 1980 que a questão ambiental começa a ganhar nova qualidade com a emergência dos movimentos populares, sobretudo camponeses como o dos seringueiros da Amazônia brasileira e dos afro-colombianos das florestas do Pacífico Sul colombiano, para o que o affair sandinista-miskitos na Nicarágua jogou um papel importante. É que na Nicarágua sandinista (1979-1989) o conflito entre matrizes de racionalidades distintas envolveu uma visão marxista, de um lado, com os sandinistas, e, de outro, os indígenas miskitos que recusavam o desenvolvimento das forças produtivas tal qual proposto por aqueles, mostrando que também à esquerda a colonialidade do saber se impunha. O mesmo seria visto mais tarde no caso TIPNIS - Terra Indígena do Parque Nacional Isiboro Secure - na Bolívia, ou no affair envolvendo os povos indígenas yukpa da Sierra de Perija, sobretudo no lado venezuelano. 
Destaquemos, aqui, que vários movimentos sociais com suas diferentes agendas, começam a se unificar em torno de lutas contra as políticas do Consenso de Washington desde o Caracazzo, de 27 de fevereiro de 1989; das Marchas pela Dignidade e pelo Território, de 1990, (Bolívia e do Equador); do Fórum do Aterro do Flamengo, paralelo à Conferência da ONU sobre Meio Ambiente e Desenvolvimento - CNUMAD, a Rio 1992, que reuniu milhares de ativistas de todo o mundo (na verdade, o $1^{\circ}$ Fórum Social Mundial) ${ }^{17}$. No dia $1^{\circ}$ de janeiro de 1994 , novamente as políticas neoliberais seriam confrontadas pelos povos originários, justamente no dia em que os EEUU, o México e o Canadá firmavam o NAFTA realizando um ajuste regional de integração com vistas a um melhor posicionamento no sistema global. Nesse dia, indígenas/camponeses, através do Exército Zapatista de Libertação Nacional, vêm novamente a público denunciar/anunciar o México Profundo, a América Profunda. E o faziam demonstrando, mais uma vez, a habilidade dos povos originários de assimilar conteúdos da sociedade global ao utilizarem amplamente a rede mundial de computadores. São os zapatistas que convocam em 1996 o primeiro grande encontro mundial contra o neoliberalismo, demonstrando o caráter local-regional-nacional e global de sua luta. O ano 2000 assistirá, na Bolívia, a primeira empresa transnacional implicada em negociatas de privatização de água, a Bechtel, ser expulsa de um país por mobilizações de rua no episódio que ficaria conhecido como Guerra del Água, em Cochabamba. Esse evento é reconhecido por vários analistas como tendo inaugurado um novo ciclo de lutas na Bolívia que levaria à deposição de vários presidentes, à Guerra do Gás (2003) e, finalmente, à eleição do primeiro presidente nascido no seio do movimento indígena, em 2005. Se o ano de 1492 pode ser tomado como marco inicial da conformação do sistema mundo moderno-colonial que habitamos, a desterrritorialização dos povos originários e as lutas por eles empreendidas estão implicadas na constituição desse mesmo sistema mundo desde o início e, deste modo, devemos entender a enorme significação do investimento político desses povos originários na Conferência Mundial de Meio Ambiente e Desenvolvimento da ONU no Rio de Janeiro em 1992. Os povos

\footnotetext{
${ }^{17}$ Nesse fórum, os povos originários tiveram um papel de destaque não só ao associarem o ano de 1992 ao ano de 1492 como também ao associarem suas diversas culturas com a natureza a uma conferência que se fazia justamente para discutir a problemática ambiental global, em grande parte fruto de uma racionalidade econômica e logocêntrica (LEFF, 2006) marcada pela idéia de dominação da natureza, enfim, contra natura, que se impusera colonialisticamente com forte componente racial contra eles.
} 
originários, os camponeses e os descendentes da diáspora africana (cimarrones, quilombolas, marroons) souberam associar o ano de 1992 ao ano de $1492 \mathrm{e}$, deste modo, sinalizaram que vivemos uma crise que é, além de histórica, civilizatória, e cuja melhor expressão foi o fato de todos os líderes de todos os estados que conformam a comunidade internacional estarem reunidos para debater temas como a terra, a água, o ar, a vida. E sobre esses temas aqueles povos e aquelas populações detêm saberes que não podem ser ignorados como o fez a colonialidade do saber e do poder que ainda reina no sistema mundo moderno colonial que nos governa. A eleição de um líder camponês-indígena na Bolívia em 2005 (e sua reeleição em 2010) é sinal de que estamos diante de uma nova agenda teóricopolítica.

\section{PARA UMA NOVA AGENDA TEÓRICO-POLÍTICA}

A crise da hegemonia ibérico-genovesa no final do século XVIII/início do XIX teve como um dos principais efeitos, ainda que não únicos, as primeiras revoluções libertadoras que ensejaram, inclusive, a afirmação da América para além de Índias Ocidentais. A intensificação das relações entre os países que se industrializavam celeremente desde então levou à reafirmação do Atlântico Norte como centro geopolítico do sistema mundo moderno-colonial, agora em sua segunda fase já não mais sob hegemonia ibérica, mas britânica e, depois, estadunidense. Essa centralidade geopolítica marca a segunda modernidade (e sua colonialidade própria) que, nos últimos 200 anos, se fez impondo uma matriz energética fossilista com uma presunção universalista tecnocêntrica que olvidou outras matrizes epistêmicas que ensejam modos de fazer (técnicas) próprios. Afinal, não há sociedade sem técnicas, ao contrário do pensamento hegemônico que acredita ser a sociedade ocidental a única fundada na técnica. $\mathrm{Na}$ verdade, a sociedade ocidental tem um modo específico de se relacionar com a técnica onde, quase sempre, ignora que a técnica, sendo do âmbito do fazer é, sempre, um fazer com sentido e, portanto, impregnada de intencionalidade, como tão bem destacara Milton Santos (SANTOS, 1996).

A América Latina e o Caribe se adaptaram a essa nova geografia política da segunda moderno-colonialidade subordinando a nossa geografia econômica à divisão internacional do trabalho como região exportadora de matérias primas agrícolas e minerais, reproduzindo internamente a colonialidade com relação às 
populações originárias e às de origem africanas. "O fim do colonialismo não significou o fim da colonialidade", conforme a fina observação de Aníbal Quijano (QUIJANO, 2005).

À medida que, hoje, a Ásia passa a ter grande dinamismo econômico a ponto de afirmar-se como pólo na nova geopolítica multipolar, se abrem para os países latino-americanos, sul-americanos particularmente, novos horizontes que proporcionam condições de romper com a dependência histórica com relação aos EEUU.

Todavia, há uma tensão territorial de novo tipo em curso e já não se trata mais do territorial confundido com a escala do estado (mono)nacional. O aprofundamento da mundialização do capital e as novas oportunidades abertas por novos meios de comunicação, como a internet, assim como a popularização dos telefones móveis, proporcionaram as condições materiais para que outros protagonistas adentrassem a arena política e colocassem em xeque o estado (mono)nacional e seu colonialismo interno. Enfim, os movimentos sociais quebraram o monopólio estatal e empresarial nas relações internacionais e contribuíram para complexificar a cena política ao se tornarem protagonistas também na escala global. O slogan "proletários de todo o mundo, uni-vos!" do Manifesto Comunista ganha uma dimensão jamais vista e com uma diversidade de sujeitos políticos inimaginável, conforme se pode ver nas diversas versões do Fórum Social Mundial ou na Via Campesina. O poder de convocação desses movimentos pode ser visto em abril de 2010 quando foi realizada a $1^{\text {a }}$ Cumbre de los Pueblos sobre Cambio Climático e Derechos de la Madre Tierra logo após o fiasco da Conferência de Copenhague de dezembro de 2009 quando o mundo financeiro começou a atuar de modo mais intenso sobre o tema do aquecimento global. Com apenas três meses de convocação, cerca de 35.000 ativistas de 142 países se reuniram em Cochabamba, cidade emblemática na luta pela reapropriação social da natureza, pano de fundo do debate ambiental (LEFF, 2006), haja vista ter sido ali que, no ano 2000, um conflito em torno da água - A Guerra da Água - envolveu camponeses, indígenas, ambientalistas e movimentos urbanos e logrou expulsar, pela primeira vez, uma empresa multinacional implicada na privatização desse bem. Observemos que os movimentos camponeses e indígenas, os campesíndios (BARTRA, 2008) ou o indigenato (Ribeiro, 1986), passam a ter um papel relevante, sobretudo a partir de 
1990, de 1992, de 1994, de 2000, de 2006, atualizando uma história de longa duração e colocando outras questões para o debate contemporâneo. Não é sem sentido que politizam o conceito de território, haja vista que o momento primeiro do sistema mundo moderno-colonial foi justamente a invasão de seus territórios, sua (des)territorialização. Para esses povos, a separação entre natureza e cultura se mostra mais que uma questão de paradigma, embora também o seja. Atualizam a história de longa duração e enriquecem o pensamento contemporâneo, sobretudo o debate no campo crítico ao capitalismo ao ampliarem o debate sobre a terra, como a questão camponesa é pensada na tradição marxista, ao colocarem a questão dos territórios. Nas palavras de um líder indígena boliviano: "não queremos terra, queremos território", o mesmo que veríamos com o líder sindical equatoriano Humberto Cholango. A luta que os camponeses e os povos originários vêm travando adquire um sentido mais amplo e diz respeito a toda a humanidade e aos destinos da vida no planeta não só por suas lutas históricas contra a desterritorialização/expropriação, mas também pela defesa das culturas em sua diversidade, posto que suas lutas implicam a defesa das condições naturais de existência com as quais desenvolveram valores que emprestam sentidos a suas práticas (cultura), daí a tríade território-territorialidade-territorialização vir adquirindo centralidade.

É que no bojo das contradições do sistema mundo moderno-colonial, acima esboçadas, em que os protagonistas eram os gestores dos organismos (que deveriam ser) multilaterais, as ONGs e as corporações do grande capital transnacional, surgiram grupos sociais, etnias e classes que reinventam sua resistência histórica à tomada de seus territórios, de suas terras e demais condições naturais de existência desde a invasão/conquista e que, sobretudo nos últimos 40 anos se viram em grande parte forçadas a viverem como populações pobres das periferias urbanas em habitações subumanas paradoxalmente mais suscetíveis a situação de riscos ambientais do que quando estavam nas áreas rurais, nos campos e nas florestas. Não olvidemos que a crise ambiental seja, na perspectiva dessas populações, também crise civilizatória, reconfigurando deste modo o debate epistêmico-político.

Com isso, definem outra agenda política onde a questão ambiental ganha outro contorno. Destarte, no debate acerca da integração regional há que se levar 
em conta esses processos de fundo a partir do que vem sendo construída outra agenda política. O avanço do capital com apoio dos estados sobre novas áreas vem engendrando tensões de territorialidades e, em seu bojo, novas questões vêm sendo formuladas a partir de outros lugares.

A Amazônia, por exemplo, tem merecido particularmente por parte da União Européia um interesse com relação ao desmatamento, pois está preocupada com as mudanças climáticas globais, e também com a biodiversidade que desaparece junto com as florestas. Do ponto de vista estadunidense, tudo indica, que os interesses sobre essa região sejam de outro tipo e mais diretos, sobretudo o controle estratégico da região em função de sua riqueza em biodiversidade e água, o que vêm perseguindo através de ações militares na Colômbia e no Peru, conforme Monica Bruckman (BRUCKMAN, 2010).

Os movimentos sociais introduziram a questão social e cultural no debate acerca da natureza. "Não há defesa da floresta sem os povos da floresta" (Chico Mendes), sintetiza bem um conjunto de lutas sociais travado em diferentes lugares do mundo: Movimento Chipko, na Índia, luta dos Chimalapas, nas selvas do sul do México (Chiapas e Oaxaca), entre os afro-colombianos do Pacífico, na Articulação dos Povos do Cerrado (Brasil), nos "acordos de pesca", nas reservas marinhas, no "salário defeso" e outras formas de configuração territorial propostas a partir dos movimentos sociais. Enfim, em diferentes contextos geográficos politizava-se a cultura, e como a cultura não é algo abstrato, essa politização trouxe o debate sobre a apropriação da natureza e, com isso, a questão territorial adquire centralidade no debate teórico-político (PORTO-GONÇALVES, 2004).

Mesmo nos países onde essas populações são pouco numerosas do ponto de vista demográfico, não o são do ponto de vista cultural e lingüístico, como no caso do Brasil onde essas populações não ultrapassam $0,4 \%$ da população total, mas falam 180 línguas distintas, cinco vezes mais que na Bolívia, onde se falam 32 línguas e a população corresponde a $62 \%$ da população total. Há aqui um dilema ético-político de novo tipo, além do direito à existência de qualquer povo e sua cultura. Além disso, essas populações ocupam áreas de alta relevância no que diz respeito à diversidade biológica e que, agora, se tornam objeto da expansão através de projetos de integração (como a IIRSA, o Plano MesoAmérica, antigo PPP) que abrem essas áreas aos interesses de grandes empresas de mineração e outras 
ávidas de terras/águas e minérios para ampliarem seus negócios de exportação de commodities. Independentemente do tamanho demográfico dessas populações, as áreas por elas ocupadas são estratégicas e, com isso, elas se inscrevem definitivamente no debate político c contemporâneo nas suas mais diferentes escalas (DIAZ-POLANCO, 2004).

Essas questões estão longe de serem rurais ou outro nome que o valha, pois são cada vez mais associadas à problemática urbana, seja pelas mudanças climáticas com chuvas torrenciais (cada vez mais concentradas no tempo), as secas rigorosas e incêndios grandiosos que se propagam, os rigores dos verões e dos invernos, as temperaturas máximas e míninas cada vez mais extremadas que, localmente, tornam a vida mais difícil de ser vivida, sobretudo para as populações que dispõem de menos condições econômicas e obrigadas a viver nos ambientes mais íngremes ou nos fundos de vales alagáveis ou ainda nos mangues; seja pela qualidade dos alimentos (orgânicos ou transgênicos, eis a questão?) associando a questão agrária à questão técnica e politizando-a; seja pela qualidade das águas; seja simplesmente pelo crescimento exponencial das cidades. A reinvenção democrática está a exigir a inserção do jogo das escalas geográficas de poder onde o local não seja subsumido num nacional abstrato (PORTO-GONÇALVES, 2001; GONZÁLEZ CASANOVA, 2007).

$O$ indígena e o camponês já não são mais o local, embora continuem sendo. Hoje, essas populações se colocam no debate político à escala nacional reconfigurando o debate com questões próprias, mas não com questões exclusivas, específicas. Colocam explicitamente a questão do poder nacional. Procuram escapar das armadilhas políticas que Ihes são postas pelo pós-modernismo e seu multiculturalismo que separa cada qual em seu canto, o que estimula o essencialismo e a xenofobia, como na Europa. Falam, ao contrário, de descolonização (Silvia Rivera Cusicanqui, Aníbal Quijano, Edgar Lander, José Angel Quintero Weyr) de interculturalidade (WALSH, 2002), de transmodernidade (DUSSEL, 2006).

Essa ampliação do debate teórico-político enseja que o estado não seja mais mono-nacional como a Bolívia explicita ao se refundar como Estado Plurinacional. $\mathrm{Na}$ última eleição realizada no país, em 2010, as populações indígenas puderam eleger seus representantes de acordo com critérios próprios e não necessariamente 
na base de cada indivíduo um voto, como na tradição liberal, uma revolução nos mecanismos políticos na medida em que reconhece a cultura para além do plano específico, mas também político-territoriais (municípios mancomunados).

O Equador, por seu turno, foi o primeiro país do mundo a introduzir os direitos da natureza numa constituição, no que foi seguido pela Bolívia. Foi no mesmo Equador que surgiu uma proposta original nascida no movimento indígenacamponês-ambientalista e acatada pelo governo Rafael Correa, de não explorar o petróleo no Parque Nacional de Yasuny localizado nos contrafortes andinoamazônicos, mediante a arrecadação de metade do valor que obteria com a exploração. É a primeira proposta concreta com relação à emissão de gases de efeito estufa que não se faz enquanto compensação dos países ricos a algum país pobre para continuar explorando e lançando esses gases na atmosfera. Aqui, deixase de explorar o petróleo em benefício das populações e da natureza em troca de captação de metade do valor para serem aplicados em projetos de energia que sejam socio-ambientalmente sustentados.

Enfim, começam a ganhar sentido ideias como pluralismo jurídico, não mais recusando os direitos das gentes, os chamados direitos consuetudinários, já não mais somente o direito hegemônico fundado nos princípios liberais do indivíduo e da propriedade privada. Afinal, o conhecimento originário e tradicional não é um direito individualizável, mas um patrimônio comum, coletivo e comunitário que demanda uma sistematização e um conhecimento que não necessariamente os reduza a princípios contrários aos seus fundamentos sociopolíticos e culturais. A maior parte das grandes corporações da área de biotecnologia sabe que não basta sair de nossos países carregando espécies botânicas e faunísticas para, a posteriori, identificar o princípio ativo em seus laboratórios. O custo disso seria incalculável. Daí seu interesse em buscar conhecimento junto a grupos sociais, povos e etnias dos seus usos originários, seja como alimento, seja como remédio. É com base nesse conhecimento originário e tradicional que recolhem as espécies de interesse para, depois, em laboratório isolarem o princípio ativo e o patentearem, ignorando a elaboração intelectual desses povos, muitos dos quais ágrafos. Portanto, o que carregam não é o que se convencionou chamar biopirataria, mas sim etnobiopirataria, pois é da cultura e do conhecimento originários que originariamente se apropriam. Só reconhecer o direito de propriedade a partir do isolamento do princípio 
ativo nos laboratórios é se apropriar indevidamente de um acervo de conhecimento ancestral que é comunitário e coletivo. Direitos de propriedade intelectual de outra ordem, enfim, novas questões teórico-políticas. Afinal, herdamos uma enorme riqueza cultural enquanto conhecimento originário e tradicional cuja origem remonta à ocupação do continente e à própria formação dos domínios clímato-botânicos (AB'SABER, 1971) abrigada no patrimônio natural de nossas florestas tropicais e equatoriais, nossas savanas, nossas estepes, nossas punas, nossos páramos e nossos mangues/humedales, enfim, a riqueza em diversidade biológica de nosso continente.

Há uma agenda positiva surgindo no interior dessas lutas sociais, muitas das quais já foram incorporadas enquanto leis ou enquanto políticas públicas. Há, muitas vezes, avanços formais com enormes dificuldades concretas de implementação, como a Lei Orgânica dos Povos Indígenas da Venezuela, uma das mais sensíveis a esse pensamento originário, mas que encontra enormes dificuldades para ser assimilada pelo próprio governo bolivariano de cujo processo revolucionário, no fundo, emergiu essa Venezuela Profunda que foi capaz de admitir essa lei. Isso se deve a uma contradição que ainda está presente entre, de um lado, uma perspectiva nacionalista, importante enquanto resistência face aos poderes globais e, de outro lado, a persistente dificuldade de entender a resistência histórica dos povos originários a esses mesmos poderes globais e, ainda, à colonialidade do saber e do poder que sobreviveu ao fim do colonialismo que ignora as formas próprias de apropriação da natureza desses povos, muitas das quais não se assentam na propriedade privada.

No Brasil, todo o esforço desencadeado pelos seringueiros e que culminou nos anos 1980 na criação das Reservas Extrativistas, que demandavam novas relações entre o Estado e a sociedade civil organizada (PORTO-GONÇALVES, 2004), se viu impossibilitada de cumprir sua verdadeira missão pelo esvaziamento do Estado nos anos de hegemonia neoliberal. Diga-se, de passagem, que a Reserva Extrativista foi a primeira sistematização de uma proposta de unidade de conservação ambiental que rompia com o paradigma que separa a natureza da cultura, como até os finais dos anos 1980 se pensavam as unidades de conservação. Nas Reservas Extrativistas, o "notório saber" das populações se coloca como condição sine qua non da conservação e, assim, um novo paradigma 
se territorializava com base na cultura dos povos e na garantia do acesso à terra como território, onde sempre há uma determinada territorialidade. O mesmo vem acontecendo com a demarcação dos territórios dos afro-brasileiros - os quilombos cujo reconhecimento formal em lei não sai do papel em função da leitura branqueada do território (Renato Emerson dos Santos), haja vista a imensidão das áreas ocupadas por essas populações, que não só foram invisibilizadas como também, muitas vezes, se mantiveram voluntariamente invisíveis como estratégia de sobrevivência, e que hoje são vistas como obstáculo às novas frentes de expansão do capital que, para esses povos, são novas frentes de invasão de seus territórios.

Há uma questão de fundo que emana desse repertório que tem permanecido invisível no debate especificamente ambiental. Trata-se da luta pela reapropriação social da natureza e da construção de sociedades sustentáveis fundadas nas condições ecológicas e culturais dos povos da terra que a humanidade, na sua diversidade, vem travando. É isso que se coloca enquanto questão territorial. Afinal, uma das condições para que haja uma dominação generalizada de alguns poucos homens sobre muitos outros é a expropriação das condições naturais da existência. É que privados dessas condições naturais pela instauração do primado da propriedade que priva - propriedade privada - se instaura a separação homemnatureza não só enquanto paradigma. Deste modo, são profundas as implicações que emanam dessas lutas pela reapropriação social da natureza, boa parte delas desencadeadas por populações com fortes vínculos territoriais, como os povos originários, camponeses, quilombolas, os sem-terra (desterritorializados em luta por re-territorialização enquanto reapropriação social da natureza).

Ao colocaram a natureza como sujeito de direito, como no Equador, ao politizarem a cultura dando-lhe um sentido prático não separando corpo e mente, natureza e cultura, espírito e matéria, ensejam um debate que vai além do desenvolvimento/subdesenvolvimento, a que o mundo intelectual ficou preso nos marcos epistêmicos eurocêntricos até recentemente. Oferecem esses movimentos sociais e seus intelectuais orgânicos (GRAMSCI, 1968) ao debate teórico-político o Suma Kawsay, o Suma Qamaña, o Buen Vivir, não como modelo, mas como outro horizonte de sentido para a vida. Afinal, não se trata de romper com o mundo onde prevalece a lógica do valor de troca sobre o valor de uso, e se pautar pela lógica do valor de uso, posto que pensar em organizar a sociedade em torno da produção de 
valor de uso é continuar sendo pautado pela lógica da produção. O par valor de usovalor de troca é parte dessa lógica que reduz tudo á economia, ou melhor, à crematística como lhe chamava Aristóteles.

Todo esse patrimônio teórico-político forjado no terreno movediço da história (a geografia) recente de nuestra América se fez enfrentando um dos mais violentos processos expropriatórios de que se tem notícia na história da humanidade. Regimes autoritários desenvolvimentistas comandaram nos últimos 40 anos a construção de estradas, barragens, hidrelétricas, linhas de transmissão que, contraditoriamente, produziram populações sem terra e sem teto, mas nesse bojo e apesar de tudo surgiu uma nova agenda teórico-política que aqui, ainda que sucintamente, explicitamos. O que passamos a assistir, sobretudo após o ano 2000 com a IIRSA - Iniciativa de Integração Regional Sul Americana - e com o Plano Mesoamérica (ex-PPP - Plan Puebla-Panamá) é a busca de integração física do continente tendo em vista as perspectivas que se abrem com a demanda por commodities pela Ásia, em particular pela China. Um novo cenário de conflitos tende a se estender, muito parecido com aquele que se estabeleceu após $1970 \mathrm{com}$ a expansão da revolução (nas relações sociais e de poder) verde, pela abertura de estradas e construção de represas e hidrelétricas, à época patrocinada por governos ditatoriais na maior parte dos países da região. Visto da perspectiva dos povos originários, camponeses e afro-americanos, entre estes, sobretudo os que vivem em pallenques, cumbes e/ou quilombos, a atual expansão vem se fazendo sobre seus territórios e, assim, recolocam o debate sobre os territórios e as fronteiras internas do colonialismo, relembrando que as fronteiras se constituem a partir de fronts, expressão que tem sua origem no campo militar, justamente para designar o espaço onde dois exércitos se defrontam e ainda não há a definição de quem o controla. Definido o controle no front, o front se torna fronteira, quase sempre se usando um rio ou uma montanha como que para indicar que a fronteira é natural, olvidando, assim, seu caráter político de origem.

Recentemente assistimos ao emblemático conflito envolvendo as populações indígenas do TIPNIS - Terra Indígena do Parque Nacional Isiboro Securé localizado nos contrafortes andino-amazônicos da Bolívia que se mobilizaram contra uma estrada que cortaria ao meio seus territórios. A estrada em questão é um dos "eixos de integração e desenvolvimento" que constitui a IIRSA e ligaria o Brasil ao 
Pacífico. Diga-se de passagem, que os maiores beneficiários dessa estrada seriam as oligarquias ligadas à exportação de commodities como os grandes latifúndios exportadores de grãos e carnes, assim como as grandes mineradoras, sobretudo do Brasil, mas também da Bolívia. Secundariamente se beneficiariam também os cocaleros, com grande poder de pressão junto ao governo de Evo Morales, ele mesmo cocalero. Enfim, para se integrar mais efetivamente aos mercados asiáticos essa integração física regional se torna imperiosa e, para isso, o Brasil dispõe de um poderoso banco de fomento, o BNDES - Banco Nacional de Desenvolvimento Econômico e Social, um dos mais importantes do mundo. No Peru, um dos movimentos sociais mais expressivos do país - a CONACAMI - Confederación Nacional de los Afectados por la Minería - se viu, em 2009, implicado num dos mais violentos conflitos dos últimos anos, em Bágua, nos contrafortes andino-amazônicos, além do caso Cajamarca, em 2011. Em Bágua morreram dezenas de pessoas, inclusive, um número expressivo de militares, no conflito protagonizado por povos indígenas em confronto com empresas mineradoras indicando sua expansão até os confins andino-amazônicos onde vivem povos em isolamento voluntário. No Brasil são tensas as relações com movimentos indígenas e camponeses acerca da construção das barragens de Belo Monte no Rio Xingu, e Jirau e Santo Antonio, no Rio Madeira, assim como na obra de transposição do rio São Francisco.

Assim, vemos ao lado desses conflitos a emergência de uma série de experiências ricas e originais de sustentabilidade: as Reservas Extrativistas, o Parque Nacional de Yasuny; os Direitos da Natureza constitucionalizados na Bolívia e no Equador; o Estado Plurinacional; o Buen Vivir, o Suma Qamaña e o Suma Kausay.

Há um cenário complexo se abrindo que coloca enormes desafios, sobretudo para aqueles que buscam uma integração com justiça social e ambiental, que abrigue a diversidade territorial de nossa região para que se logrem outros horizontes de sentido, novos ou não. Há um acervo enorme tanto de idéias para constituir uma agenda política nesse sentido, como um rico patrimônio cultural e natural que nos servem de condição para reinventar a nossa existência. 


\section{REFERÊNCIAS}

AB'SABER, Aziz 1970. Províncias geológicas e domínios morfoclimáticos no Brasil. Geomorfologia, São Paulo, v.20, p. 1-25, 1970.

ABRAMOVAY, Ricardo. Reduzir a desigualdade entre os indivíduos para combater o aquecimento global. Boletim da Sociedade Brasileira de Economia Ecológica, $n$. 23/24, p. 12-15, Jan./Ago. 2010.

BARTRA, Armando. El Hombre de hierro: los limites sociales y naturales del capital. México: Ed. Universidade Autônoma da Cidade do México, 2008.

BRUCKMAN, Monica. Ou inventamos ou erramos: a nova conjuntura latinoamericana e o pensamento crítico. 2010. Tese (Doutorado) - Programa de PósGraduação em Ciência Política, Universidade Federal Fluminense, 2010.

CAMPOS, Nazareno. Terras de Uso comum. Florianópolis: Ed. UFSC, 2011.

CARSON, Rachel. Primavera Silenciosa. São Paulo: Ed. Melhoramento, 1962.

CASTRO, Josué de. Subdesenvolvimento: causa primeira da poluição In: CASTRO, Josué de. Fome: um tema proibido. Rio de Janeiro: Civilização Brasileira, 2003.

CORNETA, Andrei. Mecanismo de Desenvolvimento Limpo e Conflitos Locais. In: ENCONTRO DE GEÓGRAFOS DE AMÉRICA LATINA, 13, 2011, San José. Anais... San José, 2011.

DIAZ-POLANCO, Hector. El canon Snorri: diversidad cultural y tolerancia. México: Universidade Autônoma da Cidade do México, 2004.

DUSSEL, Enrique. Europa, modernidade e eurocentrismo. In: LANDER, Edgardo. A Colonialidade do saber: eurocentrismo e ciências sociais. Buenos Aires; São Paulo: E. Clacso, 2006.

ENZENSBERG, Hans Magnus. Para una crítica de la ecologia política. Cuadernos Anagrama, Barcelona, 1973. 
ERLICH, Paul. Population Bomb. Estados Unidos: Sierra Club; Ballantine Books; Stanford University, 1968.

ESTERMAN, Josef. La filosofía Andina. Quito: Ed. Abya Yala, 2006.

FURTADO, Celso. O Mito do Desenvolvimento econômico. São Paulo: Ed. Paz e Terra, 1974.

GEORGESCU ROEGEN, Nicholas. The Entropy Law and the Economic Process. Cambridge: Harvard, 1971.

GONZALEZ CASANOVA, Pablo. O Colonialismo interno revisitado. In: BORÓN, Atílio. O Marxismo Hoje. Buenos Aires; São Paulo: Clacso, 2007.

HAESBAERT, Rogério. Regional/global. Rio de Janeiro: Ed. Bertrand, 2011.

HARVEY, David. O Novo imperialismo. São Paulo: Ed. Loyola, 2005.

HASBAERT, Rogério. O Mito da desterritorialização. Rio de Janeiro: Ed. Bertrand, 2004

HERNANDEZ, Efrayn. Revalorización capitalista de la Amazonía. Geopolítica y gestión estratégica de la riqueza biológica amazónica brasileña. 2005. Dissertação (Mestrado em Estudos Latinoamericanos) - Facultade de Filosofía e Letras, Universidade Nacional Autónoma de México, 2005.

LEFF, Enrique. Racionalidade ambiental: a reapropriação social da natureza. Rio de Janeiro: Ed. Civilização Brasileira, 2006.

MARTÍNEZ ALIER, Jean. La crisis económica vista desde la economía. América Latina en Movimiento, 11 abr. 2008. Disponível em:

<http://alainet.org/active/27247>. Acesso em: 23 dez. 2010.

MAX-NEEF < Manfred. El mundo en rumbo de colision. Conferencia realizada na Universidade Internacional de Andalucía em 12 jan. 2009. Disponível em: <http://www.blip.tv/file/2951120>. Acesso em: 23 fev. 2011.

MEADOWS, Paul. Os limites do Crescimento. São Paulo: Ed. Perspectiva, 1972. 
MURRA, John. Formaciones económicas y políticas del mundo andino. Lima: Instituto de Estudios Peruanos, 1975.

PACKARD, Vance. Estratégia do Desperdício. São Paulo: Ed. Ibrasa, 1965.

PEREIRA, João Marcio. O Banco Mundial como ator político, intelectual e financeiro (1944-2008). 2009. Tese (Doutorado) - Programa de Pós-Graduação em História, Universidade Federal Fluminense, Niterói, 2009.

POLANYI, Karl. A Grande Transformação: as origens da nossa época. Rio de Janeiro: Ed. Campus, 1980.

PORTO-GONÇALVES, Carlos Walter. Da geografia às geo-grafias: um mundo em busca de novas territorialidades. In: CECEÑA, Ana Ester. La Guerra Infinita. Buenos Aires: Clacso, 2001. Disponível em: $<$ http://www.foeeurope.org/publications/2009/Overconsumption_Sep09.pdf>.

PORTO-GONÇALVES, Carlos Walter- Geografando nos varadouros do mundo da territorialidade seringalista à territorialidade seringueira. Brasilia: Ed. Ibama, 2004

PORTO-GONÇALVES, Carlos Walter. A Globalização da natureza e a natureza da globalização. Rio de Janeiro: Ed. Civilização Brasileira, 2006.

PORTO-GONÇALVES, Carlos Walter. Latifundios genéticos y existencia indígena, Revista Chiapas, n. 14, p. 7-30, 2002

QUIJANO, Aníbal. 2000 Colonialidade del poder y clasificación social. Journal of world-systems research, v. 2, p. 342-386, 2000. Special Issue.

QUIJANO, Aníbal. Dom Quixote e os moinhos de vento na América Latina. Revista de Estudos Avançados, v. 19, n.55, 2005.

RAFFESTIN, Claude. Por uma geografia do poder. São Paulo: Ed. Ática, 1985. RIBEIRO, Darci. América Latina, a pátria grande. Rio de Janeiro: Guanabara, 1986.

SACK, Robert. Human Territoriality: its theory and history. Cambridge: Cambridge University Press, 1985. 
SANTOS, Boaventura de Souza. Reconhecer para libertar - os caminhos do cosmopolitismo multicultural. Rio de Janeiro: Ed. Civilização Brasileira, 2003.

SANTOS, Boaventura Souza. Refundación del Estado en América Latina. 2010.

SANTOS, Milton. A Natureza do espaço. São Paulo: Ed. Hucitec, 1996.

SAUSEN, T. M. et al. Projeto EDUCA SeRe III: Atlas de Ecossistemas da América do Sul e Antártica através de Imagens de Satélite. In: SIMPÓSIO BRASILEIRO DE SENSORIAMENTO REMOTO, 12, 2005, Goiânia. Anais... Goiânia, 2005.

TAPIA, Luis. La invención del núcleo comum: ciudadnía y gobierno multisocietal. La Paz: Ed. Muela del Diablo, 2009.

WALSH, Catherine. Interculturalidad, reformas constitucionales y pluralismo jurídico. Boletin ICCI - RIMAI do Instituto Científico de Culturas Indígenas, ano 4, n. 36, mar. 2002.

Dossiê:

Recebido em: 06/06/2012

Aceito em: 10/07/2012 